\title{
Analisis Dinamika Molekuler Pengaruh Suhu Tubuh Terhadap Keseimbangan Volume Human Serum Albumin (HSA) Menggunakan Model Potensial Lennard-Jones
}

\author{
Muhammad Rasyid Sidik ${ }^{(1, a) *}$, Yanti Yulianti ${ }^{(1, b)}$, dan Dwi Asmi ${ }^{(1, c)}$ \\ (1) Jurusan Fisika, Universitas Lampung, Bandar Lampung, Indonesia, 35141 \\ Email : ${ }^{\left(a^{*}\right)}$ mrasyidsidik28@gmail.com, ${ }^{(b)}$ yanti.yulianti@fmipa.unila.ac.id, ${ }^{(c)}$ dwiasmi82@yahoo.com
}

Diterima (04 Januarii 2020), Direvisi (10 Juli 2020)

\begin{abstract}
The research about molecular dynamics of the body temperature effect on the volume equilibrium body serum by HSA be used to Lennard-Jones potential model has been done. In this research has variation of temperature $35^{\circ} \mathrm{C}, 37^{\circ} \mathrm{C}$, and $40^{\circ} \mathrm{C}$ in the cubic system form at Gromacs application and to the determine internal energy values be used Lennard-Jones potential model. These results was at $35^{\circ} \mathrm{C}$ has the RMSD values 2,6-9,0 nm and the oncotic pressure affect in the body. Furthermore, the variation of temperature has to internal energy values $7,97 \times 10^{5} \mathrm{~kJ} / \mathrm{mol}$, $6,78 \times 10^{5} \mathrm{~kJ} / \mathrm{mol}$, and $7,89 \times 10^{5} \mathrm{~kJ} / \mathrm{mol}$.
\end{abstract}

Keywords: molecular dynamics, GROMACS, human serum albumin, Lennard-Jones, body temperature

\begin{abstract}
Abstrak. Penelitian ini telah dilakukan dinamika molekuler pengaruh suhu tubuh terhadap keseimbangan volume cairan HSA menggunakan model potensial Lennard-Jones dengan variasi suhu $35^{\circ} \mathrm{C}, 37^{\circ} \mathrm{C}$, dan $40^{\circ} \mathrm{C}$ dalam bentuk sistem kubik pada aplikasi GROMACS. Penelitian ini untuk mengetahui energi dalam perubahan suhu tubuh terhadap keseimbangan volume cairan HSA menggunakan model potensial Lennard-Jones. Hasil penelitian menunjukkan bahwa ketika adanya perubahan suhu menyebabkan destabilisasi volume cairan HSA dikarenakan adanya perubahan dalam struktur asam amino HSA yang paling sering terjadi konformasi yaitu pada suhu $35^{\circ} \mathrm{C}$ dengan perbedaan ukuran jarak rata-rata antar atom RMSD pada struktur HSA yaitu 2,6-9,0 $\mathrm{nm}$ dan mempengaruhi tekanan onkotik di dalam tubuh. Energi rata-rata dalam interaksi antar atom HSA pada suhu $35{ }^{\circ} \mathrm{C}$ sebesar $7,97 \times 10^{5} \mathrm{~kJ} / \mathrm{mol}, 37^{\circ} \mathrm{C}$ sebesar $6,78 \times 10^{5} \mathrm{~kJ} / \mathrm{mol}$, dan $40{ }^{\circ} \mathrm{C}$ sebesar $7,89 \times 10^{5} \mathrm{~kJ} / \mathrm{mol}$.
\end{abstract}

Kata kunci: dinamika molekuler, gromacs, human serum albumin, Lennard-Jones, suhu tubuh. 


\section{PENDAHULUAN}

Suhu tubuh merupakan salah satu tanda vital yang menggambarkan kesehatan seseorang dikarenakan didalam tubuh energi panas dihasilkan oleh jaringan aktif, alat keringat, lemak, tulang, jaringan ikat serta saraf. Kemudian energi panas yang dihasilkan didistribusikan ke seluruh tubuh melalui peredaran darah [1]. Hal inilah sifat perubahan suhu tubuh sangat mempengaruhi masalah klinis yang dialami setiap orang [2]. Namun, panas dari aliran darah ke kulit sama dan jumlah panas yang hilang ke luar lingkungan sehingga manusia merupakan homeotherm yaitu organisme yang mempertahankan suhu tubuh tidak bergantung lingkungannya [3].

Didalam aliran darah tubuh manusia mengandung plasma darah yang mempunyai salah satu jenis protein, protein merupakan salah satu fungsi dan elemen struktural yang berperan penting dalam sel tubuh makhluk hidup. Protein tersusun dari rantai molekul monomer yang panjang membentuk bahan struktural jaringan tubuh. Ikatan peptida terbentuk dari gabungan asam amino melalui sintesis dehidrasi menjadi polipeptida yang membentuk menjadi protein. Beberapa fungsi protein diantaranya sebagai elemen struktural, sintesis hormon, enzim dan antibodi, serta terlibat dalam transportasi oksigen [4]. Komposisi asam amino dalam ikatan peptida akan menentukan sifat dari struktur protein. Struktur protein dibagi atas empat bagian yaitu struktur primer, struktur sekunder, struktur tertier dan kuartener [5]. Dalam aktivitas protein banyak faktor yang mempengaruhi stabilitas termal protein, terutama pada mekanisme yang menjelaskan stabilitas protein yang masih menjadi masalah utama dan tidak dapat dipahami sepenuhya [6].

Pada protein yang terdapat di plasma darah banyak ditemukan albumin. Albumin ini memiliki berat molekul yang tinggi dibandingkan dengan beberapa jenis protein lain yang terdapat dalam darah [7]. Jumlah protein albumin terdapat sekitar $60 \%$ di dalam tubuh manusia dan memiliki berbagai fungsi yang sangat penting bagi kesehatan yaitu pembentukan jaringan sel baru, mempercepat pemulihan jaringan sel tubuh yang rusak, serta memelihara keseimbangan cairan didalam pembuluh darah dengan cairan di rongga interstitial dalam batasbatas normal dan albumin dapat mengatur tekanan onkotik pada tubuh [8].

Dinamika molekuler merupakan suatu metode simulasi dengan media komputer yang memungkinkan merepresentasikan interaksi molekul-molekul atom dalam jangka waktu tertentu. Dalam simulasi dinamika molekuler memainkan peran penting untuk memberikan informasi rincian skala atom yang terkait dalam studi molekuler. Simulasi dinamika molekuler dapat dilakukan dengan menggunakan program seperti Amber dan Gromacs. Program Gromacs merupakan program simulasi dinamika molekuler dengan menggunakan pendekatan persamaan hukum newton dan mekanika klasik serta di dasarkan pada mekanika kuantum [9][10][11].

Salah satu model potensial yang sering digunakan dalam simulasi dinamika molekuler adalah metode potensial LennardJones. Ciri khas dari potensial ini adalah adanya fungsi batas (cut off function) yang membatasi jumlah atom yang terlibat selama perhitungan potensial yang bekerja pada suatu atom, sehingga dengan fungsi batas ini, atom-atom yang jauh terpisah dari suatu jarak tertentu yang lebih jauh dapat diabaikan sehingga mengurangi jumlah perhitungan [12].

Pada penelitian ini, menggunakan Human Serum Albumin (HSA) sebagai sampel yang akan disimulasikan seperti Gambar 1. HSA yang merupakan polipeptida rantai tunggal dengan 585 residu asam amino dengan massa molekul terhitung sekitar $66 \mathrm{kD}$ (atau setara 66,248 D) [13]. 


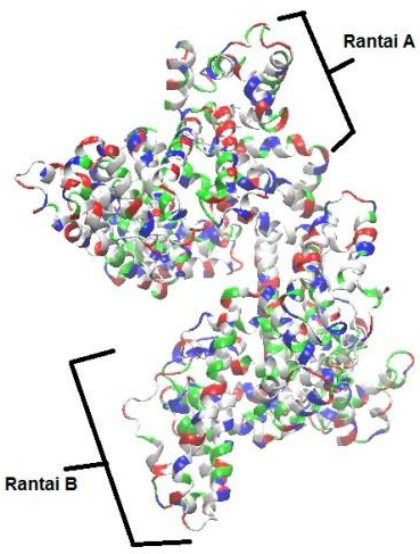

Gambar 1. Human Serum Albumin (HSA)

HSA yang digabungkan dengan bahan lain dapat mempengaruhi dinamika serta stabilitas termal melalui perubahan struktur dan situs pengikatan [14]. Salah satu peran utama HSA adalah menjaga tekanan onkotik darah dengan mengubah kerapatan permukaan ke tingkat yang sesuai. Sehingga ketika adanya peningkatan volume cairan HSA menyebabkan penurunan kerapatan, yang menyebabkan tekanan onkotik menurun mengakibatkan darah kehilangan cairan. Untuk mengetahui pengaruh perubahan suhu tubuh terhadap keseimbangan volume cairan HSA maka dilkakukan penelitian pada HSA dalam dinamika molekuler dengan menggunakan model potensial Lennard-Jones.

\section{METODE PENELITIAN}

Simulasi dinamika molekuler dilkakukan dengan menggunakan Groningen Machine for Chemical Simulation (Gromacs) 5.1.2. dengan sistem operasi Ubuntu 18.04 'Bionic Beaver'. Untuk penelitian ini menggunakan bahan yang diunduh Human Serum Albumin (HSA) dari Research Collaboratory for Structural Bioinformatic Protein Data Bank (RCSB PDB) dengan kode file 1ao6.pdb yang memiliki 2 cabang yaitu A dan B dengan jumlah atom sebanyak 9198 atom. HSA ditempatkan ditengah kubik dengan jarak 1,5 nm atau mempunyai sisi 11,19 nm kemudian diisi dengan molekul air Simple Point Charge (SPC). HSA merupakan salah satu jenis protein yang mudah terlarut dalam air kemudian diberikan medan gaya (force field) bertujuan agar ikatan asam amino tidak terganggu dengan molekul air yang dibatasi algoritma SETTLE dan menerapkan batasan pada panjang ikatan dengan algoritma Linear Constrain Solver (LINCS). Sehingga mengatur molekul air dengan batas periodik. HSA mempunyai muatan negatif yang tinggi sehingga agar sistem setimbang harus ditambahkan 1,5 $\mathrm{M} \quad \mathrm{NaCl}$ lalu dilakukan 50.000 step perhitungan energi minimalisasi agar sistem tidak terpengaruh dari energi luar sistem dengan batas periodik energi sistem $1.000 \mathrm{~kJ} / \mathrm{mol}$.

Kemudian dilakukan kesetimbangan menggunakan ensemble kanoikal (NVT) dan isothermal-isokhorik (NPT) dengan variasi suhu $35{ }^{\circ} \mathrm{C}, \quad 37{ }^{\circ} \mathrm{C}$, dan $40{ }^{\circ} \mathrm{C}$ yang berdasarkan persamaan 1 dan persamaan 2.

$$
\begin{aligned}
& K=\frac{3}{2} N k_{b} T \\
& P=\frac{2}{3} \frac{N}{V} K
\end{aligned}
$$

Dimana $\mathrm{K}=$ Energi kinetik $(\mathrm{J}), \mathrm{N}=$ Jumlah molekul, $\mathrm{k}_{\mathrm{b}}=$ Konstanta boltzman, $\mathrm{T}=$ Suhu $(\mathrm{K}), \mathrm{P}=$ Tekanan $(\mathrm{Pa})$, dan $\mathrm{V}=$ Volume $\left(\mathrm{nm}^{3}\right)$.

Simulasi dinamika molekuler dilakukan dengan 1.000 ps. Algoritma verlet digunakan untuk mengetahui letak suatu atom dalam waktu dan keadaan tertentu. Persamaan algoritma verlet dapat ditunjukkan persamaan 3 . Kemudian analisis simulasi dinamika molekuler dilakukan dengan Root Mean Standart Deviation (RMSD) dan perhitungan energi 
potensial interaksi antar atom dalam ikatan asam amino berdasarkan persamaan 4 .

$$
\vec{r}_{l}(t+\Delta t)=2 \vec{r}_{l}(t)-\vec{r}_{l}(t-\Delta t)+\vec{a}_{l}(t) \Delta t^{2}+\mathrm{O}\left(\Delta t^{4}\right)
$$

Dengan $\mathrm{r}=$ Posisi $(\AA), \mathrm{t}=$ Waktu $(\mathrm{s}), \Delta \mathrm{t}$ $=$ Perubahan waktu (s), dan $o=$ Konstanta.

$$
U\left(r_{i j}\right)=4 \varepsilon\left[\left(\frac{\sigma}{r_{i j}}\right)^{12}-\left(\frac{\sigma}{r_{i j}}\right)^{6}\right]
$$

Dimana $U=$ Energi potensial $(\mathrm{J}), \varepsilon=$ Konstanta kekuatan interaksi atom $(\mathrm{J} / \mathrm{mol})$, $\sigma=$ Panjang interaksi muatan $(\AA)$, dan $\mathrm{r}=$ Jarak antar atom $(\AA)$, sehingga besar gaya untuk potensial Lennard-Jones seperti persamaan 5 [15].

$\vec{F}_{l}=-\sum_{j \neq i} 24 \frac{\varepsilon \sigma^{6}\left(\vec{r}_{i}-\vec{r}_{j}\right)}{r_{i j}{ }^{8}}\left(1-2\left(\frac{\sigma}{r_{i j}}\right)^{6}\right)$

\section{HASIL DAN PEMBAHASAN}

\section{Pengaruh Variasi Suhu Saat Kesetimbangan}

Berdasarkan Gambar 2 terjadi perubahan pelipatan struktur albumin yang dipengaruhi oleh suhu yang berbeda. Perubahan pelipatan struktur albumin dengan bentuk Licorice, pada suhu $35{ }^{\circ} \mathrm{C}$ terjadi pada beberapa asam amino yaitu Thr566 dan Gln580 dengan jarak 20,9 A, Lys444 dan Met446 dengan jarak 5,76 A, Asn61 dan Cys62 dengan jarak 3,9 A, Glu570 dan Ser579 dengan jarak 18,09 A, dan juga Gly431 dan Cys438 dengan jarak 11,43 A. Pada suhu $37{ }^{\circ} \mathrm{C}$ yang mengalami pelipatan struktur asam amino yaitu Ile513 dan Cys514 mempunyai jarak 3,75 , Pro303 dan Glu311 mempunyai jarak 12,78 Å, Asn267 dan Ser270 mempunyai jarak

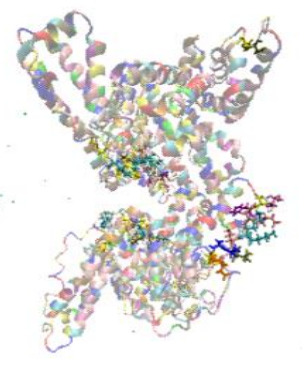

(a)

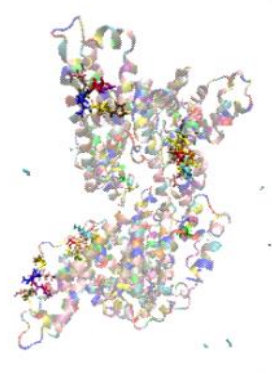

(b)

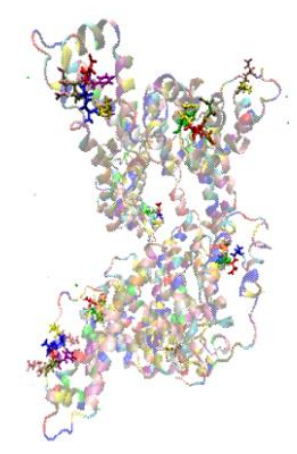

(c)

Gambar 2. Perubahan struktur albumin hasil simulasi dengan suhu (a) $35^{\circ} \mathrm{C}$, (b) $37^{\circ} \mathrm{C}$, dan (c) $40^{\circ} \mathrm{C}$.

4,65 Å, Leu275 dan Cys279 mempunyai jarak $7 \AA$ A. Sedangkan pada suhu $40{ }^{\circ} \mathrm{C}$ pelipatan struktur yang terjadi yaitu Ser304 dan Glu311 dengan jarak 11,38 Å, Asn267 dan Ile271 dengan jarak 7,75 A, Asn61 dan Cys62 dengan jarak 3,9 A, dan juga Ala511 dan Cys514 dengan jarak 4,86 ̊. 
Mekanisme pada perubahan struktur albumin ini mengalami adanya transisi dari keadaan asli ke denaturasi dengan suhu menginduksi denaturasi albumin sangat kompleks dan menyebabkan destabilisasi interaksi nonkovalen didalam albumin. Kemudian ikatan kovalen bersifat eksotermis sehingga mengalami destabilisasi pada suhu tinggi dan mengalami stabilisasi pada suhu rendah. Akan tetapi, interaksi hidrofobik bersifat endotermis, sehingga mengalami destabilisasi pada suhu rendah dan mengalami stabilisasi pada suhu tinggi. Selanjutnya pada ikatan hidrogen antar ikatan peptida kebanyakan berada didalam bagian struktur protein, sehingga tetap stabil pada berbagai kisaran suhu [16]. Ketika suhu sistem meningkat, kelarutan HSA meningkat, strukturnya berubah, dan volumenya meningkat. Perubahan dalam struktur dan volume HSA ini dalam air murni menunjukkan mengapa tubuh kehilangan air sehingga menyebabkan tekanan osmotik menurun [17].

\section{Hasil Analisis RMSD}

RMSD merupakan parameter yang diukur berdasarkan perbedaan jarak antar atom [18]. Berdasarkan Gambar 3 dari simulasi selama 0 ps sampai dengan 1.000 ps, setiap sampel mengalami peningkatan yang relatif stabil menunjukkan bahwa telah terjadinya proses perubahan konformasi dan pelipatan struktur protein.

Kemudian terjadi interaksi antar residu sehingga protein cenderung untuk mempertahankan posisinya dan adanya residu lain yang membuat protein cenderung mempertahankan strukturnya. Nilai RMSD berada pada kisaran 2.6-9,0 nm, karena hasil tersebut mengalami peningkatan sehingga nilai terendah dan nilai teringgi pada RMSD awal dan akhir dalam waktu 1.000 ps.

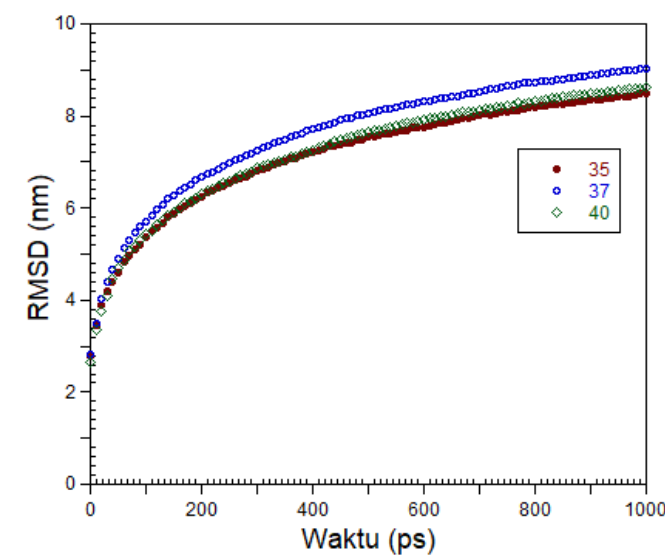

Gambar 3. Grafik analisis RMSD pada simulasi albumin dengan suhu $35^{\circ} \mathrm{C}, 37^{\circ} \mathrm{C}$, dan $40^{\circ} \mathrm{C}$.

\section{Energi Dalam Interaksi Antar Atom $\mathrm{HSA}$}

Berdasarkan Gambar 4 terlihat bahwa perbedaan fluktuasi nilai energi pada ketiga sampel cenderung stabil. Ketika ligan mencari sisi ikatan atau koordinasi dalam keadaan struktur protein dengan dipengaruhi oleh suhu menyebabkan adanya perubahan struktur protein sehingga jumlah ikatan yang berinteraksi dengan jumlah atom atom, jarak antar atom serta besar nilai atom penyusunnya menjadi berubah.

Pada sampel $35^{\circ} \mathrm{C}, 37{ }^{\circ} \mathrm{C}$, dan $40^{\circ} \mathrm{C}$ besar energi rata-rata dari interaksi Van der Waals dengan perhitungan Lennard-Jones yaitu $7,97 \times 10^{5} \mathrm{~kJ} / \mathrm{mol}, 6,78 \times 10^{5} \mathrm{~kJ} / \mathrm{mol}$, dan $7,89 \times 10^{5} \mathrm{~kJ} / \mathrm{mol}$.

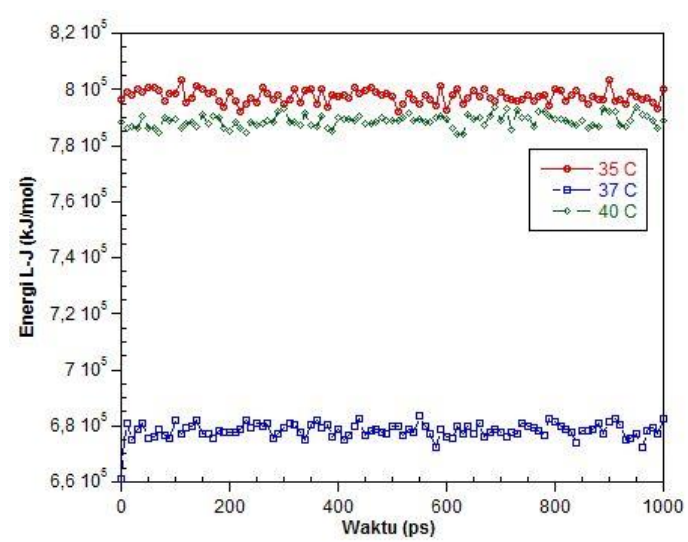

Gambar 4. Grafik Lennard-Jones dalam Energi albumin. 


\section{KESIMPULAN}

Simulasi dinamika molekuler volume cairan HSA yang berjalan dengan fungsi waktu menunjukkan perubahan suhu menyebabkan destabilisasi volume cairan HSA dikarenakan adanya perubahan dalam struktur asam amino HSA yang paling sering terjadi konformasi yaitu pada suhu $35{ }^{\circ} \mathrm{C}$ dengan perbedaan ukuran jarak rata-rata antar atom RMSD pada struktur HSA yaitu 2,6-9,0 nm dan mempengaruhi tekanan osmotik di dalam tubuh. Energi rata-rata dalam interaksi antar atom HSA pada suhu $35{ }^{\circ} \mathrm{C}$ sebesar $7,97 \times 10^{5} \mathrm{~kJ} / \mathrm{mol}, 37{ }^{\circ} \mathrm{C}$ sebesar $6,78 \times 10^{5} \mathrm{~kJ} / \mathrm{mol}$, dan $40{ }^{\circ} \mathrm{C}$ sebesar $7,89 \times 10^{5} \mathrm{~kJ} / \mathrm{mol}$.

\section{DAFTAR PUSTAKA}

[1]. Kukus, Y., Supit, W., dan Lintong, F. 2009. 'Suhu Tubuh: Homeostatis dan Efek Terhadap Kinerja Tubuh Manusia'. Jurnal Biomedik. Vol. 1. No. 2. pp. 107-118.

[2]. Wangean, L. Z., Lintong, F., dan Rumampuk, J. F. 2016. 'Pengaruh lamanya paparan energi panas terhadap suhu tubuh dengan metode mandi uap pada wanita dewasa'. Jurnal e-Biomedik (eBm). Vol. 4. No. 1. pp. 238-241.

[3]. Kuht, J., dan Farmery, A., D. 2018. 'Body temperature and its regulation', Anaesthesia \& Intensive Care Medicine. Vol. 9. No. 6, pp.259-263.

[4]. Hati, J. 2014. Analisis Kestabilan Protein 1GB1 Menggunakan Simulasi Dinamika Molekul. Bogor: Institut Pertanian Bogor.

[5]. Yuwono, T. 2005. Biologi Molekuler. Jakarta: Erlangga.

[6]. Osguthorpe, J. D. 2000. Ab Initio Protein Folding. UK: Claverton Down Bath.

[7]. Kim, Y. I., Park, J. M., Lee, Y. H.,
Choi, D. Y., dan Kwak, W. S. 2015. 'Effect of By-product Feed-based Silage Feeding on the Performance, Blood Metabolites, and Carcass Characteristics of Hanwoo Steers (a Field Study)', Asian-Australasian Journal of Animal Sciences (AJAS). Vol. 28. No. 2. pp. 180-187.

[8]. Murray, R. K., Granner, D. K., dan Rodwell, V. W. 2009. Protein plasma dan imunoglobulin. Dalam: Buku ajar Biokimia harper. Edisi 27. Jakarta: EGC.

[9]. Allen, M. P. 2003. 'Introduction Molecular Dynamics Simulation', Computational Soft Matter: From Synthetic Polymers to Proteins, Lecture Notes, Norbert Attig, Kurt Binder, Helmut Grubmüller, Kurt Kremer (Eds.). Vol. 23. pp. 1-28.

[10]. Allen, M. P. 2003. 'Introduction Molecular Dynamics Simulation', Computational Soft Matter: From Synthetic Polymers to Proteins, Lecture Notes, Norbert Attig, Kurt Binder, Helmut Grubmüller, Kurt Kremer (Eds.). Vol. 23. pp. 1-28.

[11]. Dipojono, H. K. 2001. 'Simulasi Dinamika Molekul (Sebuah Pengantar)', in Prosiding Seminar Nasional Hamburan Neutron dan Sinar X ke 4. Bandung.

[12]. Supriyadi dan Nasrudin. 2010. 'Simulasi Dinamika Molekuler: Dampak dan Prospeknya untuk Pengembangan Media Penyimpan Energi', in Seminar Nasional Tahunan Teknik Mesin (SNTTM). Palembang. pp. 113-119.

[13]. Moran, J., dan Worthely, L. I. G. 1999. 'Albumin and resuscitation: a sense of Deja Vu', Critical Care and Resuscitation. Vol. 1. pp. 110-112.

[14]. Behbehani, G. Rezaei ; Barzegar, L. 2012. 'A Thermodynamic Study on the Binding of Human Serum Albumin with New synthesized Anticancer 
Pd(II) Complex', Oriental Journal Of Chemistry. Vol. 28. No. 4. pp. 16511657.

[15]. Qi, W. H., Wang, M. P., dan Hu, W. Y. 2004. 'Calculation of The Cohesive energy of Metallic Nanoparticles By the Lennard-Jones', Materials Letters. Vol. 58. pp. 1745-1749.

[16]. Teti Estiasih; Harijono; Elok Waziiroh; Kiki Fibrianto. 2016. Kimia dan Fisik Pangan. Bumi Aksara. Jakarta.
[17]. Zergani, F. Roohizadeh, Mohammad Reza Namdari, Mehrdad Farokhnia, Abdolhady Sobhany, Yaghoub Ghayour, dan Omid. 2012. 'In Silico Study of Global Structure of Human Serum Albumin', International Journal of Green Nanotechnology. Vol. 4. pp. 511-515.

[18]. Becker Oren M., Alexander D. MacKerell, Jr. Benoît Roux, M. W. 2001. Computational Biochemistry and Biophysics. New York: Marcel Dekker, Inc. 
Muhammad Rasyid Sidik dkk.: Analisis Dinamika Molekuler Pengaruh Suhu Tubuh Terhadap Keseimbangan Volume Human Serum Albumin (HSA) Menggunakan Model Potensial Lennard-Jones 